\title{
The role of university libraries in supporting the management information needs of academic Heads of Departments
}

\author{
FRANCIS GREENE \\ Department of Information Studies \\ Sheffield University
}

\section{Introduction}

Perceptions of the role of academic heads of departments have altered in recent years. The impetus given by such reports as The Jarrat Report (1985) $)^{(1)}$, changes to the way universities are financed, and current management practices within universities, have resulted in Heads of Departments taking on greater managerial responsibility for financial and human resources as well as continuing to lead teaching and research in their departments. Similarly, university libraries are faced with the new opportunities presented by electronic delivery of services, and are having, in a tighter financial climate, to attempt to bring their services much closer to the needs of customers.

In this report the interim results of semi-structured interviews with eight university librarians are presented. These interviews are part of a larger project, funded by the BLRDD, into the management information needs of academic Heads of Departments and the role university libraries and administrators play in supplying management information to them. The project, which developed out of an earlier pilot study into the management information needs of academic Heads at Sheffield University ${ }^{(2)}$, has used a critical success factors approach to identify the organizational goals of Heads of Departments, the factors that were critical to the achievement of those goals, and the information necessary to manage these factors.

\section{The sample}

The project began by developing a sample of universities based on size, age, status, subject mix and geographical location. It was decided to exclude federal, private and specialized institutions and institutions in Scotland, Wales and Northern Ireland as the project did not have the time or finances to support visits to these areas. In all, sixteen universities were chosen; nine were former polytechnics with the other seven being older universities. Semi-structured interviews with the librarian, a university administrator of some description, and two or three academic Heads of Departments were conducted in each of the sixteen institutions. Departments were chosen were on the basis of their rating in the last Research Assessment Exercise, the proportion of postgraduates within the departments and to reflect the range of disciplines found in the universities. University administrators - registrars, heads of industrial liaison offices, heads of finance, heads of student services (careers), and planning officers - were interviewed to reflect the variety of services offered to Heads of Departments.

\section{The interviews}

Eight librarians from the sample of universities were interviewed. Based on Sumsion's typology ${ }^{(3)}$, two of the librarians worked in pre-1960s institutions, one in a 1960-1992 institution, and five in 1992 universities (former polytechnics). For each of the librarians the questionnaire focused on five areas: the general structure and mission of the university library; the library's role within the institution; the future of their library post-Follet; the nature of their services to academic Heads of Departments; and their role in supplying management information to academic Heads of Departments. 


\section{The libraries}

Each of the eight librarians confirmed that increased student numbers, a falling unit of resource, modularization and the changing structure of the student population had placed increased pressure on their mission to support teaching, learning and research in their institution. Each, given their institution's particular history, mission and structure, had responded individually to these demands. For the librarians in newer universities, the main challenges were coping with burgeoning student demands and responding to the research needs of academic staff. These research needs, driven by their institution's wish to develop a research culture, had led the librarians, under the strategic direction of the university, to target resources into what one librarian described as 'research hotspots'. As for coping with student demand the general aims were to make students more self-sufficient and exploit the possibilities that new electronic information sources offered. The newer university librarians welcomed the recommendations of The Follett Report $(1993)^{(4)}$. They felt that Follett had echoed many of the developments already occurring at their institutions. The librarians were content with the emphasis on an access rather than a holdings policy for their libraries. This reflected the nature of their collections, which, with one exception, were principally geared to meeting the teaching needs of students and staff. The librarians also welcomed the increased use of electronic material as a way of delivering resources cost-effectively and enhancing their collections. For one librarian, keen to move towards a more comprehensive electronic environment, the aim was to see the library as an open learning resource with materials being principally delivered electronically. Other librarians from the newer universities were more sceptical about this as they felt that it was too early to talk of the demise of the print medium, especially given the problems with such issues as the copyright of journals and monographs.

The librarians from the older universities agreed that there was still a vital role for print although they too wished to make much more use of such resources as BIDS and UnCover to deliver services. However, they also felt, much more than their colleagues in newer universities, that it was important to work more closely with academic departments if they were to deliver their services effectively. One, for example, commented that the devolution of financial responsibility to academic cost centres for the acquisition of monograph material had made them 'particularly concerned about the whole issue of our links with departments and the way in which information flows both ways between us'.

\section{The provision of information to academic Heads of Departments}

However, when we turn to the actual provision of information to departments, all of the librarians interviewed felt that their efforts were not targeted at the Head of Department level. Instead, libraries concentrated much more on the relationship between subject specialists within the library and the relevant person in departments. Librarians also had difficulty in targeting information to Heads of Departments because all librarians saw no reason to discriminate between their customers. Subsequently, as Heads of Departments have, on the whole, only a sparse amount of time for research and teaching, the librarians felt they used the services of the library less than any user group.

Despite this, the librarians were able to characterize the information they supplied to Heads of Departments. These results are presented in the ranked table below: 
Table.1 Types of information provision to academic Heads of Departments

$\begin{array}{ll}\text { Support for ongoing research } & 8 \\ \text { Developing new courses } & 7 \\ \text { Financial management information } & 7 \\ \text { Competitor intelligence } & 5 \\ \text { Research funding alternatives } & 5 \\ \text { Student scholarships and awards } & 5 \\ \text { Links with extra-mural bodies } & 5 \\ \text { Developments in higher education } & 5 \\ \text { Improving teaching skills } & 5 \\ \text { Links with industry } & 4 \\ \text { Performance indicators } & 4 \\ \text { Travel awards } & 3 \\ \text { Developing other resource alternatives } & 2 \\ \text { Developing exchange programmes } & 1\end{array}$

Of these fourteen types of information only the first two were systematically provided. Support for ongoing research was central to the mission of the libraries and librarians felt it important to be involved in developing new courses. Principally, this was because the librarians were concerned about the resource implications of new, and often additional, courses. All the libraries were involved at some point in the validation process for new courses. However, this was not formalized in all the libraries. For one, it was a rather unsystematic process whilst for another the procedures were in place but the library always seemed to become involved at too late a stage in the process to make any real input.

As for financial management information and, for that matter, performance indicators, the librarians indicated that this referred solely to information on their activities. In general, this was not systematically delivered. Data was made available to Heads of Department either directly, through the library's annual report, or to committees such as Senate, but the librarians perceived that Heads of Departments were very busy people and the library only really became an issue when it proposed cuts to the periodicals budget. In the two cases where library resources had been devolved to departments, contact between the library and the department differed markedly. One university, born post-Robbins, had sought to introduce service level agreements with departments as 'the best way of ensuring that we get the optimum benefit from the resources available'. The other, older university, had not yet arrived at this position and felt that this was due to their lack of contact with departments.

As for the other types of information, whether internally or externally focused, the story, as one librarian put it, was where 'in the best library manner we hold the information but do not do anything with it'. Information on competitor intelligence or links with industry was for all libraries delivered on an ad hoc and informal basis. This general picture, of course, varied from library to library, with some libraries supplying rather more focused information dependent upon the nature and mission of the library and the degree of involvement between subject specialists within the library and individuals in the departments.

In terms of management information, librarians suggested that the university did not expect them to act as a source of such information. At best, librarians felt that their role was to supply 
information about the performance of their library and act as a secondary source of information. There are several reasons why the librarians took this view. They principally cited that it was not their role but the role of other, more specialized, agencies in the university to deliver management information. Moreover, librarians felt that they faced enough challenges as it was, with one librarian suggesting, that "to be honest, our priority at the moment is coping with our budget situation, putting through our restructuring and still maintaining our services to the users'. To go beyond that, could mean 'if we run something on our own initiative there is a danger that it would be perceived as looking around for something to do and having spare resources to do it with'.

These difficulties were compounded by the librarians' difficulties in focusing on Heads of Departments. In many institutions there may be more than twenty Heads of Departments, each with individual and eclectic information needs. The librarians did recognize that the role of the Head of Department has become much more managerial over recent years but this, if anything, had further distanced libraries from Heads of Departments, since librarians principally saw their role as being to support students, teachers and researchers rather than those managing departments.

What this has to say for information strategies rather than information technology strategies in universities is a moot point. It seems clear from the interviews that librarians only see a limited role for their libraries in supplying management information to academic Heads of Departments. There is a certain lack of awareness amongst the librarians interviewed about the information needs of academic Heads of Departments. One, for example, admitted that 'I do not know what the needs of academic Heads of Department are'. At the same time, however, it seems just as clear that the librarians feel that the principal responsibility for the supply of management information rests elsewhere. How well this is done elsewhere, what the academic Heads of Departments perceive their needs to be, and whether the other eight university librarians agree with these conclusions, will be discussed when the final results from the project are published.

\section{References}

1. Jarratt, A. Report of the Steering Committee for Efficiency Studies in Universities (the Jarratt Report). London: CVCP, 1985.

2. Pellow, A. and Wilson, T.D. The management information requirements of heads of university departments: a critical success factors approach, Journal of Information Science: Principles \& Practice. 19, 1993, pp 425-437.

3. Sumsion, J. Survey of resources and uses in higher education libraries, UK 1993. Loughborough: Loughborough University of Technology Library and Information Statistics Unit, 1994.

4. Follett, B (chair). The Joint Funding Councils Libraries' Review Group Report (the Follett Report). London: HEFCE, SHEFC, HEFCW, DENI, 1993. 